\title{
Estimation of chemical composition, in vitro gas production, metabolizable energy, net energy lactation values of different peanut varieties and line by Hohenheim in vitro gas production technique
}

\section{Estimativa da composição química, produção de gás in vitro, energia metabolizável, energia líquida dos valores de lactação de diferentes variedades de amendoim e linha pela técnica de produção de gás in vitro Hohenheim}

Tugay Ayasan ${ }^{1 *}$; Ismail Ulger2; Ayse Nuran Cil3; Vincenzo Tufarelli4; Vito Laudadio4; Valiollah Palangi ${ }^{5}$

Highlights

Peanut is rich in amino acids, minerals, and vitamins and crude protein.

Waste from agricultural processing factories is one of the sources of environmental pollution.

The use of new feed sources as animal feedstuff is necessary.

\begin{abstract}
This study was carried out to determine the nutritional value of some selected peanut varieties and line in the Eastern Mediterranean Agricultural Research Institute of Adana, Turkey. The peanut varieties used were Gazipasa, Sultan, NC7, Cihangir, and Halisbey; while the peanut line was DA335/2011. The chemical composition, metabolizable energy (ME), net energy lactation (NEL) and organic matter digestibility (OMD) of the selected peanut varieties and line were determined through Hohenheim in vitro gas production technique. Incubation times for Hohenheim gas production technique were 3, 6, 9, 12, 24, 48, 72 and 96 hours. The analysis of variance (General Linear Model) was carried out using the SPSS package program.

1 Associate Prof. Dr., Osmaniye Korkut Ata University, Kadirli Academy of Applied Sciences, Osmaniye, Turkey. E-mail: tayasan@gmail.com

2 Associate Prof. Dr., Erciyes University Agricultural Faculty, Department of Animal Science, Kayseri, Turkey. E-mail: i_ ulger@hotmail.com

3 Dr., East Mediterrenean Agricultural Research Institute, Adana, Turkey. E-mail: aysenurcil@hotmail.com

${ }^{4}$ Profs. Drs., Section of Veterinary Science and Animal Production, University of Bari 'Aldo Moro, Valenzano, Italy. E-mail: vincenzo.tufarelli@uniba.it; vito.laudadio@uniba.it

${ }^{5}$ Dr., Department of Animal Science, Agricultural Faculty, Ataturk University, Erzurum, Turkey. E-mail: valiollah. palangi12@ogr.atauni.edu.tr

* Author for correspondence
\end{abstract}

Received: Nov. 16, 2020 - Approved: Feb. 04, 2021 
The differences among groups in terms of nutrient contents were found to be significant $(P \leq 0.05)$, except for dry matter (DM) and hemicellulose (HC). The highest crude protein (CP) (40.13\%) was found in Sultan variety, while the crude oil (CO) content was found to be between 21.32 and $31.01 \%$. The ADF, NDF, and ADL content of the peanut varieties and line were within the ranges of $2.32-7.91 \%, 4.85-9.88 \%$, and $0.43-2.62 \%$, respectively. Conversely, the Sultan variety had the highest crude cellulose (CC) value, Cihangir variety was determined to contain the highest hemicellulose $(\mathrm{HC})$ value. The differences in 24 hour gas and methane production among different peanut varieties and line were found to be not-significant. $(P>0.05)$.

Key words: Peanut. Nutrient composition. In vitro gas production. Metabolizable energy.

\section{Resumo}

Este estudo foi realizado para determinar o valor nutricional de algumas variedades e linhagens de amendoim selecionadas no Eastern Mediterranean Agricultural Research Institute de Adana, Turquia. As variedades de amendoim utilizadas foram Gazipasa, Sultan, NC7, Cihangir e Halisbey; enquanto a linha de amendoim foi DA335 / 2011. A composição química, energia metabolizável (ME), energia líquida de lactação (NEL) e digestibilidade da matéria orgânica (OMD) das variedades e linhagens de amendoim selecionadas foram determinadas através da técnica de produção de gás in vitro de Hohenheim. Os tempos de incubação para a técnica de produção de gás Hohenheim foram 3, 6, 9, 12, 24, 48, 72 e 96 horas. A análise de variância (General Linear Model) foi realizada com o programa SPSS Package. As diferenças entre os grupos quanto aos teores de nutrientes foram significativas ( $P \leq 0,05)$, exceto para matéria seca $(M S)$ e hemicelulose $(H C)$. A maior proteína bruta (PB) (40,13\%) foi encontrada na variedade Sultan, enquanto o teor de óleo bruto (CO) ficou entre 21,32 e 31,01\%. O conteúdo de ADF, NDF e ADL das variedades e linha de amendoim estava dentro dos intervalos de 2,32-7,91\%, 4,85-9,88\% e 0,43-2,62\%, respectivamente. Por outro lado, a variedade Sultan teve o maior valor de celulose bruta (CC), e a variedade Cihangir foi conteve o maior valor de hemicelulose (HC). As diferenças na produção 24 horas de gás e metano entre as diferentes variedades de amendoim e linha foram consideradas não significativas. $(P>0,05)$.

Palavras-chave: Amendoim. Composição de nutrientes. Produção de gases in vitro. Energia metabolizável.

\section{Introduction}

Peanut (Arachis hypogaea L.), an oil seed plant from the legume (Faboceae) family, is rich in amino acids, minerals, and vitamins and contains $40-60 \%$ fat and $25 \%$ crude protein (CP) (Sahin, 2014). Hepsag (2018) stated that peanut seeds contain $45-55 \%$ fat, $20-25 \%$ protein, $16-18 \%$ carbohydrate, and $5 \%$ mineral substances such as $\mathrm{K}, \mathrm{Ca}, \mathrm{Mg}, \mathrm{P}$, and $\mathrm{S}$, as well as the vitamins $\mathrm{A}, \mathrm{B}$, and $\mathrm{E}$.

Recently, the agricultural wastes have been started to be used successfully in animal and poultryfeeding (Arıoglu, 2014; Azizi, Seidavi,
Ragni, Laudadio, \& Tufarelli, 2018; Seidavi, Azizi, Ragni, Laudadio, \& Tufarelli, 2018). There are many advantages of using food by-products such as peanut, and these advantages include the suitability for crop rotation, making good use of the nutrients in the cropland, and leaving a clean, semi-treated, and nitrogen-rich soil to the next plant. In addition, its importance increases even more thanks to fact that the peanut pulp and its green parts can be successfully used as forage and its shell in food or feed industry (Kokten, Kaplan, Seydesoglu, Ozdemir, \& Boydak, 2014). Moreover, using agroindustrial by-products in animal nutrition 
has been successfully adopted as a strategy to reduce feeding costs and to cope with the need to recycle waste material, which is costly to dispose of (Tufarelli, Introna, Cazzato, Mazzei, \& Laudadio, 2013). Thus, also peanut by-product could be a valuable alternative ingredient because of its low price compared with conventional raw material, where the peanut oil industries play an important economic role. Moreover, an opportunity to capture a share of the by-product feed market may exist for peanut oil processors currently disposing of their peanut waste.

In a previous study, the animal nutritional values of hays from different peanut (Arachis hypogaea) varieties were examined, and it was assessed that Florispan and Arığlu-2003 varieties, which were among the 10 varieties used, differed with their higher CP and DM consumptions compared to other varieties (Kokten, Kaplan, Seydesoglu, Ozdemir, \& Boydak, 2014).

Arıoglu, Bakal, Gulluoglu, Kurt and Onat (2016) found that the CO contents of different peanut seed varieties [Halisbey, Sultan, NC7, Osmaniye 2005, Batem 5025, Florispan, Brantley, Wilson, Georgia Green, Ha-runner, Flower 22 (V-1), Flower 32 (V-2), and Flower 36 (V-3)] were within the range of $47-51 \%$ and their CP contents were within the range of $24-28 \%$. In their study determining the $\mathrm{CP}$ contents of Gazipasa, Sultan, DA35/2011, and NC-7; Macar, Macar, Cil, Oluk and Cil (2018) reported that Cihangir and Halisbey varieties and line, NC-7 variety had the highest $\mathrm{CP}$ content (30.6\%), followed by the DA35/2011 line with $29.6 \%$. There was no statistically significant difference between the CP levels of Sultan (26.9\%) and Cihangir (27.2\%) varieties, and the same occurred for Gazipaşa (27.7\%) and Halisbey (27.8\%) varieties. In another study, the
$\mathrm{CP}$ contents of peanut varieties, as potential animal feed, were found to be between 24.80 and $29.60 \%$, and the average CP content was 26.84\% (Kılınccerker \& Arıoglu, 2019).

Therefore, based on previous trials, the purpose of this study was to determine the nutritional value of different peanut seed varieties (Gazipasa, Sultan, NC7, Cihangir, and Halisbey) and line (DA335/2011) in the Eastern Mediterranean Agricultural Research Institute under the conditions of Adana in Turkey.

\section{Materials and Methods}

This study was carried out with peanut that was grown on the fields of Eastern Mediterranean Agricultural Research Institute located in Doğankent in Adana under conditions typical of peanut production in Turkey.

\section{Feed material}

The feed material of the study consisted of different peanut varieties (Gazipasa, Sultan, NC7, Cihangir, and Halisbey) and line (DA335/2011) grown in the Eastern Mediterranean Agricultural Research Institute, Adana, Turkey. Each variety was planted in 5 parcels and a sample of $1 \mathrm{~kg}$ was taken from each parcel for each variety. 5 repetitions were taken from each feed.

\section{Soil material}

Soil samples were taken before sowing and the necessary analyzes were conducted to determine needs for fertilizer. A standard application of 8-10 $\mathrm{kg} \mathrm{P}_{2} \mathrm{O}_{5} /$ dekare and 5-6 $\mathrm{kg} \mathrm{N} /$ dekare was applied to the entire peanut production area into the bottom. $15 \mathrm{~kg}$ of urea 
was added to the top. The peanut planter was adjusted to ensure a planting depth of $6 \mathrm{~cm}$ and seeds were spaced $15 \mathrm{~cm}$ apart on the ridges.
The rows are arranged to be $70 \mathrm{~cm}$. Chemical analysis results of soil samples are shown in Table 1.

\section{Table 1}

\section{Chemical analysis of soil samples}

\begin{tabular}{ccccccc} 
Organic matter & $\mathrm{P}_{2} \mathrm{O}_{5} \%$ & $\mathrm{~K}_{2} \mathrm{O}$ & $\mathrm{pH}$ & $\mathrm{EC}\left(\mathrm{dSm}^{-1}\right)$ & Lime, $^{2}$ & Saturation, \% \\
\hline 1.04 & 3.16 & 63.06 & 7.82 & 0.437 & 16.36 & 53.25
\end{tabular}

The soil structure of the peanut production areas was light-alkaline, salt-free and clayey-loamy. Its content was high in lime, low in organic matter (OM). Saturation is $53.25 \%$. Available $\mathrm{K}_{2} \mathrm{O}$ is good; available P2O5 is low.

During the peanut growing season, $213.3 \mathrm{~mm}$ of precipitation was received. The highest average value for rainfall as $\mathrm{mm}$ was observed in March at $115.8 \mathrm{~mm}$. Table 2 shows the temperature, humidity and precipitation amounts of peanuts. The highest average value for air temperature was observed in August at $29.6^{\circ} \mathrm{C}$. According to the long-term average, the average temperature of the peanut growing period in Adana location is $22.4^{\circ} \mathrm{C}$. The highest average value for relative humidity was observed in July at $69.3 \%$. According to the long-term average, the relative humidity of the peanut growing period in Adana location is $66.3 \%$

\section{Chemical analyses}

The samples of five different peanut species and lines as seed were sent to the feed laboratory in the Department of Zootechnics, Faculty of Agriculture, Erciyes University, where the nutrient analyses were carried out.

\section{Table 2}

\section{Weather during the growing season for peanut}

\begin{tabular}{ccccccc} 
& Air & Temperature, ${ }^{\circ} \mathrm{C}$ & Relative & Humidity, \% & Rainfall, & mm \\
\cline { 2 - 7 } Months & $\begin{array}{c}\text { Long years } \\
\text { average }\end{array}$ & Mean & $\begin{array}{c}\text { Long years } \\
\text { average }\end{array}$ & Mean & $\begin{array}{c}\text { Long years } \\
\text { average }\end{array}$ & Mean \\
\hline March & 13.3 & 13.9 & 65.1 & 64.6 & 65.4 & 115.8 \\
\hline April & 17.3 & 15.8 & 66.8 & 62.5 & 51.2 & 7.9 \\
May & 21.6 & 21.7 & 66.0 & 64.3 & 47.3 & 81.0 \\
June & 25.5 & 24.2 & 66.7 & 69.1 & 20.5 & 0.0 \\
\hline July & 28.0 & 28.0 & 66.6 & 69.3 & 6.3 & 0.0 \\
August & 28.4 & 29.6 & 66.7 & 62.1 & 5.6 & 8.6 \\
\hline Total & 22.4 & 22.2 & 66.3 & 65.3 & 196.3 & 213.3 \\
\hline
\end{tabular}


The dry feed samples were first ground in a mill having a sieve diameter of $1 \mathrm{~mm}$ and then used for the analyses. In order to determine the DM content, the ground samples were kept in an oven at $70^{\circ} \mathrm{C}$ for 24 hours and the differences between the weights before and after baking were computed and expressed in DM \%. In order to determine the CA content, the samples were burned in a muffle furnace at $550^{\circ} \mathrm{C}$ for 4 hours. Kjeldahl method was used to determine the nitrogen $(\mathrm{N})$ content. The crude protein (CP) content was computed using the following formula: $\mathrm{CP} \%=\mathrm{N} \times 6.25$ (Association of official Analytical Chemists [AOAC], 1990). The crude oil (CO) analysis was carried out as per the method reported by AOAC (1990) using SER148 Soxhlet (Velp Scientifica, Milan, Italy). The NDF and ADF contents constituting the cell wall components of the feeds were determined as per the methods reported by Van Soest, Robertson and Lewis (1991) using ANKOM 200 fiber analyzer (ANKOM Technology, NY, USA). In computing the $\mathrm{CC}$ values, the following equation, reported by Pinkerton (2005), was used: $\mathrm{CC} \%=0.80 \times \mathrm{ADF} \%$. The $\mathrm{HC}$ contents were computed by subtracting the ADF values from the NDF values. In computing the NFC values, the following equation by Weiss, Conrad and St Pierre (1992) was used: NFC \% $=100-($ NDF $\%+C P \%+C O \%+C A \%)$.

\section{In vitro gas production}

For the in vitro gas production (GP), the feeds were in vitro incubated with rumen fluid supplied from the fistulated sheep in glass syringes in accordance with the principles specified by Menke \& Steingass (1988). Then, $100 \mathrm{ml}$ syringes were supplemented with $0.200 \mathrm{~g}$ of dry samples. The syringes with only the rumen fluid were incubated and used as blank. The incubations were carried out in three replicates. The pre-warmed syringes $\left(39^{\circ} \mathrm{C}\right)$ were filled with $30 \mathrm{ml}$ of rumen fluid buffer mixture and incubated in a water bath at $39^{\circ} \mathrm{C}$. Gas production readings were taken before (0) and 24 hours after the incubation. The resultant GP values were corrected for blank and hay standards.

The following equations by Menke, Raab, Salewski, Steingass and Fritz (1979) were used to calculate metabolizable energy (ME), net energy lactation (NEL), and organic matter digestibility (OMD) of the silage samples:

$\mathrm{ME}(\mathrm{Mcal} / \mathrm{kg} \mathrm{DM})=(2.20+0.1136 \times \mathrm{GP}+0.0057$ $\left.\times \mathrm{CP}+0.00029 \times \mathrm{CO}^{2}\right) / 4.184$

NEL $($ Mcal $/ \mathrm{kg} \mathrm{DM})=(1.64+0.269 \times \mathrm{GP}+$ $\left.0.00078 \times \mathrm{GP}^{2}+0.0051 \times \mathrm{CP}+0.01325 \times \mathrm{CO}\right)$ / 4.186

$\mathrm{OMD}(\%)=14.88+0.889 \times \mathrm{GP}+0.45 \times \mathrm{CP}+$ $0.0651 \times \mathrm{CA}$

\section{Statistical analyses}

The analysis of variance (General Linear Model procedure) was carried out using the Statistical Package for the Social Sciences [SPSS] (1999) package program to determine the differences among the means. The Duncan's multiple comparison test was also used to determine the significance levels of the differences.

\section{Results and Discussion}

The dry matter (DM), CA, CP, and CO; the ADF, NDF, and ADL; and the crude cellulose $(\mathrm{CC})$, hemi cellulose $(\mathrm{HC})$, and NFC contents of the peanut varieties and line were shown in the Tables 3, 4, and 5, respectively. The $24 \mathrm{~h}$ in vitro 
gas and methane production, metabolizable energy (ME), net energy lactation (NEL) ingredients of the peanut varieties and line when incubated with rumen buffered liquid in vitro were shown in the Table 6.
As can be seen from the Tables 3, 4, and 5 ; the differences between the varieties and line in terms of $\mathrm{CA}, \mathrm{CP}$, and $\mathrm{CO}$ contents $(P<0.05)$; the ADF, NDF, and ADL contents ( $P$ $<0.05)$; and the CC and NFC contents $(P<0.05)$ were found to be statistically significant.

Table 3

Dry matter (DM), CA, CP, and CO contents of the peanut varieties and line

\begin{tabular}{|ccccc|}
\hline Variety and line & DM, \% & CA, \% DM & CP, \% DM & CO, \% DM \\
\hline Gazipasa & 96.39 & $2.60^{\mathrm{c}}$ & $34.76^{\mathrm{c}}$ & $21.99^{\mathrm{c}}$ \\
\hline NC-7 & 96.83 & $2.45^{\mathrm{d}}$ & $38.42^{\mathrm{b}}$ & $25.38^{\mathrm{bc}}$ \\
\hline Cihangir & 96.81 & $2.75^{\mathrm{ab}}$ & $38.59^{\mathrm{b}}$ & $28.99^{\mathrm{ab}}$ \\
\hline Sultan & 96.53 & $2.72^{\mathrm{b}}$ & $40.13^{\mathrm{a}}$ & $31.01^{\mathrm{a}}$ \\
\hline DA 2011-335 & 96.33 & $2.51^{\mathrm{d}}$ & $39.37^{\mathrm{ab}}$ & $21.32^{\mathrm{c}}$ \\
\hline Halisbey & 96.29 & $2.80^{\mathrm{a}}$ & $39.18^{\mathrm{ab}}$ & $24.97^{\mathrm{bc}}$ \\
\hline SEM & 0.082 & 0.039 & 0.529 & 1.127 \\
\hline P & 0.180 & $<0.001$ & $<0.001$ & 0.014 \\
\hline
\end{tabular}

DM: Dry matter; CA: Crude ash; CP: Crude protein; CO: Crude oil; SEM: Standard error of means; a,d: The values in a column with different superscripts differ significantly at $\mathrm{P}<0.05$.

Table 4

ADF, NDF and ADL contents of the peanut varieties and line

\begin{tabular}{cccc}
\hline Variety and line & ADF, \% DM & NDF, \% DM & ADL, \% DM \\
\hline Gazipasa & $3.38^{\text {cd }}$ & $5.79^{c}$ & $1.69^{\mathrm{b}}$ \\
\hline NC-7 & $3.56^{\mathrm{c}}$ & $5.66^{\mathrm{c}}$ & $0.68^{\mathrm{d}}$ \\
\hline Cihangir & $5.21^{\mathrm{b}}$ & $7.90^{\mathrm{b}}$ & $1.92^{\mathrm{b}}$ \\
Sultan & $7.91^{\mathrm{a}}$ & $9.88^{\mathrm{a}}$ & $2.62^{\mathrm{a}}$ \\
DA 2011-335 & $5.18^{\mathrm{b}}$ & $7.85^{\mathrm{b}}$ & $1.07^{\mathrm{c}}$ \\
Halisbey & $2.32^{\mathrm{d}}$ & $4.85^{\mathrm{c}}$ & $0.43^{\mathrm{d}}$ \\
SEM & 0.552 & 0.532 & 0.229 \\
P & $<0.001$ & 0.001 & $<0.001$
\end{tabular}

ADF: Acid detergent fiber; NDF: Neutral detergent fiber; ADL: Acid detergent lignin; SEM: Standard error of means; ${ }^{\text {add: }}$ The values in a column with different superscripts differ significantly at $P<0.05$. 
Table 5

Crude cellulose (CC), hemi cellulose (HC), and NFC contents of the peanut varieties and line

\begin{tabular}{|cccc|}
\hline Variety and line & CC, \% DM & HC, \% DM & NFC, \% DM \\
\hline Gazipasa & $1.69^{\mathrm{e}}$ & 2.41 & $34.86^{\mathrm{a}}$ \\
\hline NC-7 & $2.88^{\mathrm{cd}}$ & 2.10 & $28.09^{\mathrm{b}}$ \\
\hline Cihangir & $3.29^{\mathrm{bc}}$ & 2.69 & $21.77^{\mathrm{c}}$ \\
\hline Sultan & $5.29^{\mathrm{a}}$ & 1.97 & $16.26^{\mathrm{c}}$ \\
\hline DA 2011-335 & $4.11^{\mathrm{b}}$ & 2.67 & $28.94^{\mathrm{b}}$ \\
\hline Halisbey & $1.90^{\mathrm{de}}$ & 2.53 & $28.20^{\mathrm{b}}$ \\
SEM & 0.387 & 0.184 & 1.847 \\
\hline P & 0.001 & 0.895 & 0.003 \\
\hline
\end{tabular}

CC: Crude cellulose; HC: Hemi cellulose; NFC: Nonstructural carbohydrate; SEM: Standard error of means; a,: The values in a column with different superscripts differ significantly at $\mathrm{P}<0.05$.

As can be seen from the Table 6, statistically significant ( $P>0.05)$. The ME and the differences between the varieties and NEL values were statistically significant in line in terms of GP, CH4, and OMD were not varieties and line $(P<0.05)$.

\section{Table 6}

The $24 \mathrm{~h}$ in vitro gas and methane production, metabolizable energy (ME), and net energy lactation (NEL) ingredients of the peanut genotypes when incubated with rumen buffered liquid

\begin{tabular}{|cccccc|}
\hline Varieties and line & $24 \mathrm{~h} \mathrm{GP,} \mathrm{ml}$ & $24 \mathrm{~h} \mathrm{CH} 4, \mathrm{ml}$ & $\mathrm{ME}, \mathrm{MJ} / \mathrm{kg} \mathrm{DM}$ & $\mathrm{NEL}, \mathrm{MJ} / \mathrm{kg} \mathrm{DM}$ & $\mathrm{OMD}, \%$ \\
\hline Gazipasa & 17 & 2.81 & $10.43^{\mathrm{c}}$ & $3.76^{\mathrm{b}}$ & 45.80 \\
\hline NC-7 & 17.5 & 2.96 & $11.37^{\mathrm{b}}$ & $4.03^{\mathrm{a}}$ & 47.89 \\
\hline Cihangir & 18 & 2.85 & $12.1^{\mathrm{ab}}$ & $4.13^{\mathrm{a}}$ & 48.43 \\
\hline Sultan & 16 & 2.73 & $12.30^{\mathrm{a}}$ & $4.04^{\mathrm{a}}$ & 47.34 \\
\hline DA 2011-335 & 14.5 & 2.47 & $10.30^{\mathrm{c}}$ & $3.73^{\mathrm{b}}$ & 45.65 \\
\hline Halisbey & 17 & 2.58 & $11.29^{\mathrm{b}}$ & $4.02^{\mathrm{a}}$ & 47.81 \\
\hline SEM & 0.395 & 0.065 & 0.238 & 0.050 & 0.372 \\
\hline P & 0.069 & 0.279 & 0.005 & 0.028 & 0.089 \\
\hline
\end{tabular}

SEM: Standard error of mean; P: Probability value; a, b, c, d: The means in the same column with different superscripts are significantly different; 24 h GP: 24 h in vitro gas production (ml/200 mg DM); 24 h CH4: in vitro methane production in total gas for a 24-hour-incubation (ml/200 mg DM); ME: metabolizable energy (MJ/kg DM); NEL: net energy lactation (MJ/ kg DM).

The DM values ranged between $96.29 \%$ and $96.83 \%$. The variation observed among the treatment groups in terms of DM content was found to be statistically insignificant $(P>0.05)$. Latif, Pfannstiel, Makkar and Becker (2013) asserted that the peanut seed contained $94.1 \%$ DM, 51.8\% CO, 26.0\% $\mathrm{CP}$, and $2.1 \% \mathrm{CA}$; while in another study, the moisture content of peanut varieties was found to be 5.63\% (Akkaya et al., 2017). The 
moisture contents of peanut varieties were determined to range between 4.12 and $4.75 \%$ by Mora-Escobedo, Hernández-Luna, JoaquínTorres, Ortiz-Moreno and Robles-Ramírez (2015), between $6.22 \%$ and $6.62 \%$ by Ginting, Rahmianna and Yusnawan (2018), as 5.25\% by Yadav, Edukondalu, Patel and Rao (2018), between 5.53 and $5.93 \%$ by Shibli, Siddique, Raza, Ahsan and Raza (2019), and between 3.93 and $4.85 \%$ by Zahran and Tawfeuk (2019). The recommended moisture content for peanuts is $6 \%$ (Barbara et al., 2012).

In our study, the CP contents of different peanut varieties and line ranged between $34.76 \%$ (Gazipasa) and 40.13\% (Sultan). The average $\mathrm{CP}$ content was calculated to be $38.41 \%$ for the peanut varieties and line. The average CP content obtained as a result of our study (38.41\%) was higher than the values found by Asibuo, Akromah, Adu-Dapaah and Kantanka (2008) (18.92-30.53\%), Zhang, Wang, Tang and Wang (2009) (26.1-28.6\%), Canavar (2011) (23.66\%), Kadiroglu (2012) (26.26-32.38\%), Asık, Yıldız and Arıoglu (2018) (20.32-32.38\%), Yadav, Edukondalu, Patel and Rao (2018) (25.48\%), and Zahran and Tawfeuk (2019) (25.07-28.20\%).

Akkaya et al. (2017) reported that the average CP content of peanut varieties was 24.94\%. Asık, Yıldız and Arıoglu (2018) determined the CP values of the Sultan, NC7, Cihangir, and Halisbey varieties, which were also used in our current study, as 24.72, $25.40,25.27$, and $24.54 \%$, respectively; while Kadiroglu (2012) found the CP contents of peanut varieties NC-7 and Halisbey as 32.38 and $29.94 \%$, respectively. The differences between the $\mathrm{CP}$ values found in the literature and in our study may have resulted from the different environmental conditions of the site where the study was carried out, the delay of the harvest time, the difference in total precipitation received and temperature during the vegetation, and the difference of varieties and lines.

In our study, the crude oil (CO) contents of peanut varieties and line were found to be within the range of $21.32-31.01 \%$, and the average CO ratio was found as $25.61 \%(P<0.05)$. The highest CO content was found in Sultan variety with $31.01 \%$. Examining the effect of harvest time on CO in peanut, Canavar (2011) asserted that the $\mathrm{CO}$ contents at each harvest time took different values, and that there was an increase in the CF contents as the harvest time was delayed. The researcher found the average CO content as $37.64 \%$. Caliskan, Caliskan, Arslan and Arıoglu (2008) found the CO content of peanuts as $49.5-52.6 \%$; while Kadiroglu (2012) as 48.58-51.07\%; MoraEscobedo, Hernández-Luna, Joaquín-Torres, Ortiz-Moreno and Robles-Ramírez (2015) as 37.90-56.31\%, Akkaya et al. (2017) as 49.07\%, Asık, Yıldızand Arıoglu (2018) as 51.42\%, Yolbas (2018) as 48.90\%, Shibli, Siddique, Raza, Ahsan and Raza (2019) as 49.80-50.90\%; and Zahran and Tawfeuk (2019) found that the fat contents in 5 different peanut varieties were within the range of $50.45-52.12 \%$.

Kadiroglu (2012) found that the CO content of NC-7 and Halisbey peanut varieties were within the range of $47.94-50.36 \%$ and 46.72-50.24\%, respectively. Kurt, Bakal, Gulluoglu, Onat and Arıoglu (2016) found the CO content of Halisbey, Sultan, and NC-7 varieties as $46.22,46.33$, and $43.71 \%$, respectively. Asık, Yıldız and Arıoglu (2018) found the CO contents of Sultan, NC7, Cihangir, Halisbey varieties, which were also used in our current study, as $50.40,52.64,49.95$ and $50.77 \%$, respectively; while Macar, Macar, Cil, Oluk and Cil (2018) stated that the $\mathrm{CO}$ content of different peanut varieties (Gazipasa, Sultan, NC7, Cihangir, and Halisbey) and line (DA335/2011) used in our 
study ranged between $43.9 \%$ and $45.9 \%$; the difference in $\mathrm{CO}$ contents of the varieties were statistically insignificant; the $\mathrm{CO}$ contents of Gazipasa, Sultan, DA35/2011, NC-7, Cihangir, and Halisbey varieties and line were 45.0, 43.9, $44.7,46.4,45.5$ and $45.9 \%$, respectively; and that NC-7 variety had the highest $\mathrm{CO}$ content. Karabulut and Tuncturk (2019) found that the CO content of NC-7, Gazipasa, Halisbey, Sultan, and Cihangir varieties were 33.6, 35.7, $36.1,37.4$ and $36.4 \%$, respectively.

The difference in the crude oil (CO) values in different studies may have resulted from the differences in the times when the trials were carried out, varieties or lines, environmental conditions, and harvest times. Cil, Cil, Akkaya and Sahin (2016) stated that the high rate of fat in peanuts was mostly caused by the genotype, and the cultivation technique and ecological factors also had an effect. Zaki, Amal, Ahmed, Hassanein and Mohamed (2018) found that the CO content was affected by variety, year, and fertilization, and the $\mathrm{CO}$ content of peanut varieties ranged between 47.78 and $48.01 \%$. In another study, it was found that the $\mathrm{CO}$ content of peanut varieties ranged between 43.54 and 47.68\% (Kılınccerker \& Arıoglu, 2019). The recommended CO content for peanuts is $45.90 \%$ (Barbara et al., 2012).

While the crude ash (CA) content of the peanut varieties and line had the lowest value in NC-7 variety with $2.45 \%$, Halisbey variety had the highest CA with $2.80 \%(P<0.05)$. In a study, it was stated that the CA content of the peanut was within the range of $2.30-2.67 \%$ (Canavar, 2011). Harvest time is one of the factors affecting $\mathrm{CA}$; and as the harvest is delayed, the CA content increases. CamposMondragón et al. (2009) reported that the CA values of 6 different peanut varieties ranged between 2.0 and 2.5\%; while Ibraheem, Kabeir, Mohammed and Bhagiel (2015) found it as
1.13\%. Mora-Escobedo, Hernández-Luna, Joaquín-Torres, Ortiz-Moreno and RoblesRamírez (2015) found the ash content of peanut varieties between 2.22 and 2.50\%, while Yadav, Edukondalu, Patel and Rao (2018) found it to be $1.84 \%$. Shibli, Siddique, Raza, Ahsan and Raza (2019) found the CA content in 3 different peanut varieties to range between 2.00 and 2.17\%. Zahran and Tawfeuk (2019) found the ash content in 5 different peanut varieties to range between 1.75 and $2.80 \%$. The recommended ash content for peanuts is 2.30\% (Barbara et al., 2012).

Containing cellulose, lignin, and hemicellulose in its structure, NDF is difficult to digest for the ruminant animals. NDF is consisted of hemicellulose, cellulose, and lignin (Sezmis \& Gursoy, 2020). Low NDF values in feed are a desirable feature for animals and associated with the increased animal feed consumption. The average NDF value was found as $6.98 \%$ in our study. The differences observed in terms of NDF in the literature stem from the ecological conditions, variety differences, and cultural applications. In a previous study, it was determined that the NDF contents of hays from different peanut varieties ranged between 34.81 and $45.66 \%$ and there was a statistically significant difference between the varieties (Kokten, Kaplan, Seydesoglu, Ozdemir, \& Boydak, 2014). In a study on this subject, it was found that the NDF values of processed peanut stalks did not differ significantly between the varieties and ranged between 53.1 and 60.7\% (OtengFrimpong, Konlan, \& Denwar, 2017).

The ADF value, an indicator of digestibility of roughages according to Van Soest (1967), was found to be $4.59 \%$ in our study on the basis of variety and line. It was emphasized in a previous study that the ADF contents of hays from different peanut 
varieties ranged between 29.60 and $39.11 \%$, and there was a statistically significant difference between the varieties (Kokten, Kaplan, Seydesoglu, Ozdemir, \& Boydak, 2014). The acid detergent lignin (ADL) content ranged between 0.43 and $2.62 \%$ in our study. The highest ADL content was obtained in Sultan variety and the lowest in Halisbey variety. In a study conducted on this subject, it was found that ADF contents of processed peanut stalks differed depending on the varieties and ranged between 43.8 and 59.4\% (Oteng-Frimpong, Konlan, \& Denwar, 2017).

The CC contents of peanut varieties and lines differed statistically significantly in this study (Table 3) and ranged between $1.69 \%$ and $5.29 \%$. Campos-Mondragón et al. (2009) reported that the cellulose content of 6 different peanut varieties were between 3.0\% and 4.4\%; while Ibraheem, Kabeir, Mohammed and Bhagiel (2015) found it as $2.08 \%$, and Shibli, Siddique, Raza, Ahsan and Raza (2019) between $4.95 \%$ and $8.53 \%$. The recommended cellulose content for peanuts is $8.50 \%$ (Barbara et al., 2012). The content of hemicellulose (HC), which is the common name for some complex carbohydrates or polysaccharides found on the walls of plant cells together with cellulose and pectin, was found to be $2.40 \%$ on average, ranging between 1.97 and $2.69 \%$ in different peanut varieties and line.

Non-fiber carbohydrate (NFC) content, a value calculated with the equation NFC $\%=$ $100-(\mathrm{NDF} \%+\mathrm{CP} \%+\mathrm{CO} \%+\mathrm{CA} \%)$, ranged between 16.26 and $34.86 \%$ depending on the varieties and line. Yang (2005) reported that NFC content of the peanut stover was $21.5 \%$, while Yuan and Wan (2019) stated that the NFC content in the peanut shell was $11.2 \%$.

Gas production is one of the most important indicators used in estimating the digestibility of feed stuff in the rumen of the ruminants (Yuan \& Wan, 2019). A 24-hour in vitro gas production and methane production of different peanut varieties were found to be statistically insignificant. Various studies have been carried out on in vitro properties of peanut and its products (Rao, Tian, Fu, \& Xue, 2018). Yang (2005) and Yuan and Wan (2019) stated that the gas production at the end of $48 \mathrm{~h}$ was $36.5 \mathrm{ml}$ in the peanut shell. When the literature of in vitro studies on peanuts is reviewed, it is seen that some studies have been carried out on hays of peanut varieties. In a study examining the in vitro gas production in the silage of peanut stalks, Oteng-Frimpong, Konlan and Denwar (2017) found that the in vitro gas production of the stalks from 6 different peanut varieties did not differ depending on the varieties.

The metabolizable energy and NEL contents led to a difference among the varieties. In terms of metabolizable energy, the Sultan variety yielded the highest value with 12.30 MJ/kg, while the DA 2011-335 line yielded the lowest value with $10.30 \mathrm{MJ} / \mathrm{kg}$. In a study conducted on this subject, it was determined that the ME values of processed peanut stalks did not lead to a difference between the varieties and ranged between 12.7 and 15.7 MJ/kg (Oteng-Frimpong, Konlan, \& Denwar, 2017). The net energy lactation value ranged between 3.73 (DA 2011-335 line) and 4.13 (Cihangir variety) $\mathrm{MJ} / \mathrm{kg}$, revealing a statistically significant difference between the varieties and line.

Being a value calculated using the net gas production (GP), CP, and CA at the end of the 24-hour incubation period of $200 \mathrm{mg}$ dry fodder sample; the organic matter digestibility (OMD) did not lead to a statistically significant difference between the varieties. In a study on this subject, it was found that the OMD values 
of the processed peanut stalks did not lead to a difference between the varieties (OtengFrimpong, Konlan, \& Denwar, 2017).

\section{Conclusions}

The main purpose of this study was to determine the nutritional contents of six different peanut varieties and line, and to determine the metabolizable energy, net energy lactation, total digestible nutrients, and digestible energy values. From findings, the highest values were observed in Sultan variety in terms of $\mathrm{CP}, \mathrm{CO}, \mathrm{ADF}, \mathrm{NDF}, \mathrm{ADL}, \mathrm{CC}$, and ME; in Gazipasa variety in terms of NEL; in Cihangir variety in terms of $\mathrm{HC}$; and in Gazipasa variety in terms of NFC. The 24-hour in vitro gas production and methane production, yet, did not lead to any difference between the varieties and lines.

\section{Authors' contributions}

TA contributed to the project idea, design and execution of the study. IU, ANC, VL and VT were in charge of laboratory analyses. TA and VP were responsible for supervision and writing the manuscript.

\section{Funding}

The authors received no specific funding for this work.

\section{Conflict of Interest Declaration}

The authors have declared that no competing interest exists.

\section{References}

Akkaya, M. R., Yucel, H., Duman, A. D., Didin, M., Ozer, E. A., \& Kola, O. (2017). Determination of some quality characteristics of peanut (Arachis hypogaea L.) using NearInfrared Reflectance Spectroscopy (NIRS). Derim, 34(1), 37-42. doi: 10.16882/ derim.2017.305312

Association of Official Analytical Chemists (1990). Official methods of analysis (14nd ed.). Arlington, Virginia: AOAC.

Arıoglu, H. H. (2014). Peanut cultivation and reclamation, Oil Plants Textbook, Ç.U. Faculty of Agriculture Publications, Chapter No: 220, Y. No: A-70, S.74, Adana.

Arıoglu, H. H., Bakal, H., Gulluoglu, L., Kurt, C., \& Onat, B. (2016). Ana ürün koşullarında yetiştirilen bazı yerfıstığı çeşitlerinin önemli agronomik ve kalite özelliklerinin belirlenmesi. Tarla Bitkileri Merkez Araştırma Enstitüsü Dergisi, 25(Özel konu 2), 24-29. doi: 10.21566/tarbitderg.281656

Asibuo, J. Y., Akromah, R., Adu-Dapaah, H. K., \& Kantanka, O. S. (2008). Evaluation of nutritional quality of groundnut (Arachis hypogaea L.) from Ghana. African Journal of Food Agriculture Nutrition and Development, 8(2), 133-149. doi: 10.4314/ ajfand.v8i2.19185

Asık, F. F., Yıldız, R., \& Arıoglu, H. A. (2018). Osmaniye koşullarına uygun yeni yerfıstığı çeşitleri ile bunların önemli tarımsal ve kalite özelliklerinin belirlenmesi. KSÜ Tarım ve Doğa Dergisi, 21(6), 825-836. doi: 10.18016/ksutarimdoga.vi.452842

Azizi, M., Seidavi, A. R., Ragni, M., Laudadio, V., \& Tufarelli, V. (2018). Practical applications of agricultural wastes in poultry feeding in Mediterranean and Middle East regions. 
Part 1: citrus, grape, pomegranate and apple wastes. World's Poultry Science Journal, 74(3), 489-498. doi: 10.1017/ S004393 3918000478

Barbara, S., Charrondiere, U. R., Enujiugha, V. N., Bayili, R. G., Fagbohoun, E. G., Samb, B., Burlingame, B. (2012). West African Food Composition Table. pp. 25-74. https://www.bioversityinternational. org/ fileadmin/_migrated/uploads/tx_news/ West_African_food_composition_ table__table_de_composition_des_ aliments_d\%e2\%80\%99Afrique de_l\%e2\%80\%990uest_1522.pdf

Caliskan, S., Caliskan, M. E., Arslan, M., \& Arıoglu, H. (2008). Effects of sowing date and growth duration on growth and yield of groundnut in a Mediterranean type environment in Turkey. Field Crops Research, 105(1-2), 131-140. doi:10.1016/j.fcr.2007.08.007

Campos-Mondragón, M. G., De La Calderon, B. A. M., Durán-Prado, A., Campos-Reyes, L.C., Oliart-Ros, R.M., Ortega-García, J., Angulo, O. (2009). Nutritional composition of new peanut (Arachis hypogaea L.) cultivars. Grasas Y Aceites, 60(2), 161167. doi: $10.3989 / g y a .075008$

Canavar, Ö. (2011). Farklı hasat zamanlarının yerfıstığının verim ve verim unsurları ile yağ asitleri kompozisyonu ve aflatoksin konsantrasyonu üzerine etkisi. Doktora Tezi, Adnan Menderes Üniversitesi Fen Bilimleri Enstitüsü Tarla Bitkileri Ana Bilim Dalı, Aydın, Türkiye.

Cil, A. N., Cil, A., Akkaya, M. R., \& Sahin, V. (2016). Çukurova koşullarına uygun geliştirilen yerfıstığı (arachis hypogaea ı.) genotiplerinin bazı tarımsal özelliklerinin belirlenmesi. Tarla Bitkileri Merkez Araştırma Enstitüsü Dergisi, 25(Special
Issue 2), 18-23. doi: 10.21566/tarbitderg. 281607

Ginting, E., Rahmianna, A. A., \& Yusnawan, E. (2018). Aflatoxin and nutrient contents of peanut collected from local market and their processed foods. IOP Conference Series: Earth and Environmental Science, 102(1), 012031. doi: 10.1088/1755-1315/ $102 / 1 / 012031$

Hepsag, F. (2018). Determination of quality characteristics of peanut paste produced in Osmaniye province. Adyütayam, 6(2), 55-66.

Ibraheem, S. E., Kabeir, B. M., Mohammed, L. H., \& Bhagiel, B. T. (2015). Nutritional composition and energy value of roasted peanut milk partially substituted with millet thin porridge fermented with bifidobacterium longum BB536. International Journal of Technology Enhancements and Emerging Engineering Research, 3(9), 63-69.

Kadiroglu, A. (2012). Yerfıstığı (Arachis hypogaea L.) yetiştiriciliğinde farklı çeşitler ve sıra üzeri mesafelere göre tek ve çift sıralı ekim yöntemlerinin karşılaştırılması. Doktora tezi, Süleyman Demirel Üniversitesi FBE Tarla Bitkileri ABD Doktora Tezi, Isparta, Türkiye.

Karabulut, B., \& Tuncturk, R. (2019). DiyarbakırBismil ekolojik koşullarında ana ürün olarak yetiştirilen yerfıstığı (arachis hypogaea I.) çeşitlerinin tarımsal ve kalite özelliklerinin araştırılması. Yüzüncü Yıl Üniversitesi Fen Bilimleri Enstitüsü Dergisi, 24(2), 97-104.

Kılınccerker, M. B., \& Arıoglu, H. (2019). Çukurova koşullarında yetiştirilen bazı virginia tipi yerfıstığı çeşitlerinin önemli kalite özelliklerinin belirlenmesi. Türkiye 13. Ulusal, 1. Uluslararası Tarla Bitkileri 
Kongresi, 01-04 Kasım, ss:245-252, Antalya.

Kokten, K., Kaplan, M., Seydesoglu, S., Ozdemir, S., \& Boydak, E. (2014). Farklı yerfıstığı (Arachis hypogaea) çeşitlerinin kuru otlarına ait hayvan besleme değerlerinin belirlenmesi. Türk Tarım ve Doğa Bilimleri Dergisi, 1(2),156-160.

Kurt, C., Bakal, H., Gulluoglu, L., Onat, B., \& Arıoglu, H. (2016). Çukurova bölgesinde ikinci ürün koșullarında bazı yerfıstığı çeșitlerinin önemli agronomik ve kalite özelliklerinin belirlenmesi. Süleyman Demirel Üniversitesi Ziraat Fakültesi Dergisi, 11(1), 112-119.

Latif, S., Pfannstiel, J., Makkar, H. P. S., \& Becker, K. (2013). Amino acid composition, antinutrients and allergens in the peanut protein fraction obtained by an aqueous enzymatic process. Food Chemistry, 136(1), 213-217. doi:10.1016/j.foodchem. 2012.07.120

Macar, T. F., Macar, O., Cil, A. N., Oluk, C. A., \& Cil, A. (2018). Assessment of peanut (Arachis hypogaea L.) genotypes in terms of some nutritional and antioxidant parameters. Süleyman Demirel University Journal of Natural and Applied Sciences, 22(3), 11751181. doi: 10.19113/sdufenbed.471805

Menke, A. H., \& Steingass, H. (1988). Estimation of energetic feed value obtained from chemical analysis an in vitro gas production using rumen fluid. Animal Feed Science and Technology, 28(7), 55.

Menke, K. H., Raab, L., Salewski, A., Steingass, H., \& Fritz, D. (1979). The estimation of digestibility and metabolizable energy content of ruminant feedstuffs from the gas production when they incubated with rumen liquor in vitro. Journal of Agricultural
Science, 93(1), 217-222. doi: 10.1017/ S0021859600086305

Mora-Escobedo, R., Hernández-Luna, P., Joaquín-Torres, I. C., Ortiz-Moreno, A., \& Robles-Ramírez, M. D. C. (2015). Physicochemical properties and fatty acid profile of eight peanut varieties grown in Mexico. CyTA-Journal of Food, 13(2), 300304. doi: 10.1080/19476337.2014.97134 5.

Oteng-Frimpong, R., Konlan, S. P., \& Denwar, N. N. (2017). Evaluation of selected groundnut (Arachis hypogaea I.) lines for yield and haulm nutritive quality traits. Hindawi International Journal of Agronomy, 7479309, 9. doi: 10.1155/2017/7479309

Pinkerton, B. (2005). Forage quality. Clemson University Cooperative Extension Service. Forage fact sheet 2. Cooperative Extension Service, Clemson University.

Rao, H., Tian, Y., Fu, W., \& Xue, W. (2018). In vitro digestibility and immunoreactivity of thermally processed peanut. Food and Agricultural Immunology, 29(1), 989-1001. doi: 10.1080/09540105.2018. 1499710.

Sahin, G. (2014). Türkiye'de yerfıstığı (Arachis hypogaea L.) yetiştiriciliği ve bir coğrafi işaret olarak Osmaniye yerfıstığı. Gaziantep Üniversitesi Sosyal Bilimler Dergisi, 13(3), 619-644. doi: 10.21547/jss. 256812

Seidavi, A. R., Azizi, M., Ragni, M., Laudadio, V., \& Tufarelli, V. (2018). Practical applications of agricultural wastes in poultry feeding in Mediterranean and Middle East regions. Part 2: tomato, olive, date, sunflower wastes. World's Poultry Science Journal, 74(3), 443-452. doi: 10.1017/ S00439339180 0051X 
Sezmis, G., \& Gursoy, E. (2020). Determination of relative feed value, net energy lactation and metabolic energy contents of alfaalfa. Fresenius Environmental Bulletin, 29(3), 1637-1642.

Shibli, S., Siddique, F., Raza, S., Ahsan, Z., \& Raza, I. (2019). Chemical composition and sensory analysis of peanut butter from indigenous peanut cultivars of Pakistan. Pakistan Journal of Agricultural Research, 32(1), 159-169. doi: 10.17582/journal.pjar/ 2019/32.1.159.169

SPSS (1999). Statistical Package for Social Sciences Chicago, Illinois, USA: SPPS Inc.

Tufarelli, V., Introna, M., Cazzato, E., Mazzei, D., \& Laudadio, V. (2013). Suitability of partly destoned exhausted olive cake as by-product feed ingredient for lamb production. Journal of Animal Science, 91(2), 872-877. doi: 10.2527/jas.20125541

Van Soest, P. J. (1967). Use of detergents in the analysis of fibrous feeds. Determination of plant cell wall constituents. Journal of the Association of Official Analytical Chemists, 50(1), 50-55. doi: 10.1093/jao ac/50.1.50

Van Soest, P. J., Robertson, J. D., \& Lewis, B. A. (1991). Methods for dietary fibre, neutral detergent fibre and non-starch polysaccharides in relation to animal nutrition. Journal of Dairy Science, 74(10), 3583-3597. doi: 10.3168/jds.S00220302(91)78551-2

Weiss, W. P., Conrad, H. R., \& St Pierre, N. R. (1992). A theoretically-based model for predicting total digestible, nutrient values of forages and concentrates. Animal Feed Science and Technology, 39(1-2), 95-110. doi: 10.1016/0377-8401(92)90034-4
Yadav, P. B., Edukondalu, L., Patel, S., \& Rao, D. B. (2018). Proximate composition of peanut milk prepared by different methods. International Journal of Current Microbiology and Applied Sciences, 7(10), 2388-2391. doi:10.20546/ijcmas. 2018.710.276

Yang, C. M. (2005). Proteolysis, fermentation efficiency, and in vitro ruminal digestion of peanut stover ensiled with raw or heated corn. Journal of Dairy Science, 88(8), 2903-2910. doi: 10.3168/jds.S0022-0302 (05)72971-4

Yolbas, M. (2018). Farklı ekim zamanlarının Siirt koşullarında yerfıstığı (Arachis Hypogaea L.)'nın verim ve verim unsurları üzerine etkisi. Yüksek Lisans Tezi, Siirt Üniversitesi Fen Bilimleri Enstitüsü, Siirt, Türkiye.

Yuan, J., \& Wan, X. (2019). Multiple-factor associative effects of peanut shell combined with alfalfa and concentrate determined by in vitro gas production method. Czech Journal of Animal Science, 64(8), 352-360. doi: 10.17221/94/2019CJAS

Zahran, H. A., \& Tawfeuk, H. Z. (2019). Physicochemical properties of new peanut (Arachis hypogaea L.) varieties. OCL, 26(19), 1-7. doi: 10.1051/ocl/2019018

Zaki, N. M., Amal, G., Ahmed, M., Hassanein, S., \& Mohamed, M. H. (2017). Effect of organic and bio-fertilizer on yield and some chemical composition of two peanut cultivars under newly reclaimed sandy soil condition. Middle East Journal of Applied Sciences, 7(4), 937-943.

Zhang, J., Wang, C., Tang, Y., \& Wang, X. (2009). Effects of grading on the main quality attributes of peanut kernels. Frontiers of Agriculture China, 3(3), 291-293. doi: 10.1007/s11703-009-0050-x 